to call on a brother physician, a student, a trained or untrained nurse or a layman to take his place. In emergency cases the anesthetic is often administered by the surgeon in charge, who at the same time is his own first and second assistant and trained nurse; and deaths from ether or chloroform are as rart in their practice as under the care of the trained anesthetizer and score of assistants in the large hospitals.

The best of men have lost cases from the anesthetic, yet they have not been censured unless it was proven that they were criminally careless. Why, then, in this case, where no carelessness has been shown, should the anesthetizer be given the blame, while the surgeon coolly excuses himself with the statement that that assistant was nnknown and untried?

The Doctor evidently had not recovered from his agitation when he wrote that a. physician who had once given ether should never be allowed to give chloroform afterwards.

Yours respectfully, WM. G. Kemper, M.D.

\section{Appendectomy-Surgical History.}

\section{Cincinnati, O., Jan. 24, 1902.}

To the Editor:-Will you kindly publish the enclosed letter bearing on the subject of early operation in appendicitis, and oblige,

\section{Yours respectfully,}

\section{B. Merrill Ricketts, M.D.}

"Ft. Wayne, IND., Jan. 21, 1902.

"Dr. B. Merrill Ricketts, Cincinnati, O.

"Dear Doctor:-'The enclosed clipping from The Journal of the American Medical Association was sent me this morning by my son, Dr. George C. Stemen, of Denver. ["AppendectomySurgical History," Page 46, this Volume.] I had overlooked this in reading The JouknaL.

"In regard to my case, I will say that on April 22, 1887, I was called in consultation to see a man said to be suffering from general peritonitis and called "perityphlitis." There was every indication that the man would die, and I said that if he would consent, I would operate on him. He not only consented but requested that it be done. I made the operation and found a large quantity of pus and a necrosed appendix almost detached. I removed it and drained, and the patient is living today. You misunderstood me when I met you at Lima, as to it being 1884; it was 1887 . The gentleman I operated on 1 s A. B. Nickey, who lives at Princeton, Ind., and is in good health.

"I thank you for mentioning my case. I am not much con cerned as to whether I made the first operation, but I certainly made one quite early in the history of this operation.

$$
\text { "Respectfully yours, }
$$

$$
\text { "C. B. Stemen, M.D." }
$$

\section{The A. M. A. as Basis of Reciprocity.}

Chattanooga, Tenn., Jan. 21, 1902.

To the Editor:- I can not just at present go into a detailed consideration of defense of the proposition, but $I$ wish to heartily endorse the suggestion made by Dr. Skelly in the last issue of THE Joursal, that membership in the American Medical Association be made the basis of reciprocity for license to practice between the various state examining boards.

With this as a foundation idea it seems to me that it is possible of elaboration so as to practically apply to this vexed question how to bar quacks and impostors, while at the same time recognizing intelligence, experience and probity towards license for practice throughout our common country, with as little of examination as may prove reasonable in compliance with laws as now existent or contemplated.

At some future date I may find opportunity for further argument on this point. At present I merely want to bring out further opinions upon the proposition, so that we may hear both sides of the question and ascertain how extensive may be the impulse to make this membership a basis for reciprocity, how practicable it is, what obstacles interpose, and how the examiners themselves receive the proposition. In a word let us "reason together" about the matter. Yours,

E. A. Cobleigi, M.D.
Tetanus Following Vaccination.

Philadelphia, Pa., Jan. 21, 1902.

To the Editor:-I. will be greatly obliged to any of your readers who may have had or know of eases of tetanus following raccination, if they will communicate with me concerning them. I am engaged in a critical analysis of such cases in the hope of determining their etiology, and desire to secure all the data possible.

Respectfully yours,

Josepil McFariand, M.D.

\section{Married.}

George Wesley BeatTy, M.T., of Brooklyn, N. S.. to Miss Caroline M. Steingester.

Harry E. Burdett, M.D., to Miss Nellie O'Gara, both of St. Paul, Minn., January 8.

Herbert Bacon, M.D., to Miss Mollie Prouse, both of Bloomville, Ohio, January 19.

Dwight Calkins, M.D., Battle Creek, Mich., to Miss Marjory E. Ryder, of Pittsburg, Pa.

Charles E. Congnon, M.D., to Miss Anna Ramsdeli, both of Nashua, N. H., January 16.

James H. Davis, M.D., Seyppel, Ark., to Miss Inus Bishop, of Belton, Texas, Dec. 23, 1901.

William S. Beaty, M.D., to Miss Estelle Bonner, both of Vineyard, Ark., January 29.

Wilmer Adams, M.D., Wye Mills, M.D., at Baltimore, to Miss Mamie R. Gould, January 15.

Henry T. Norment, M.D., Anthoston, Ky., to Mrs. Virginia Norment, Henderson, Ky., January 16.

Hermax S. Spear, M.D., New Portland, Me., to Miss Evelyn Conant, of South Strong, Maıne, January 1.

Frederick Phineas Drake, M.D., London, Ont., to Miss Ada Kibbee Wright, of Port Huron, Mich., January 15.

William N. MCArtney, M.D., Fort Covington, N. Y., to Miss Caroline Claghorn, assistant superintendent of the Lackawanna Hospital, Seranton, Pa., January 15.

\section{Deaths and Obituaries.}

Sylvester D. Bell, M.D. Western Reserve University, Cleveland, Ohio, 1874, formerly a practitioner of Butler, Pa., but for the past few years a resident of Arizona, a member of the Medical Society of the State of Pennsylvania and of the American Medical Association, died at his home in Tucson, January 14 . He was a presidential elector in 1892 , and had lield several responsible territorial appointments.

Frederick Gundrum, M.D. Miami Medical College, Cincinnati, 1868, who had practiced for several years in Indiana, going thence to California on account of his health, died at his home in Riverside, January 13, from asthma complieating la grippe, after an illness of three days, aged 57 . He was a member of the American Medical Association.

Kingston Goddard, M.D. University of Pennsylvania, Philadelphia, 1860, a contract surgeon in the Civil war, and thereafter for many years a practitioner of Philadelphia, coroner, and member of the Board of Education, who retired from active practice several years ago, died at the residence of lis son in Philadelphia, January 18, aged 62.

James Farrington, M.D. New York University, 1847, one of the oldest physicians of Rochester, N. H., died at his home in that place, January 18 , aged 80 . He was a member of the Strafford District and New Hampshire State Medical societies and had served as a member of the legislature, of the constitutional convention and of the governor's council.

John Brownrigg, M.D. Jefferson Medical College, Philadelphia, 1851, formerly a surgeon in the Confederate service, one of the most prominent physicians of Mississippi, and a resident of Columbus, died January 21, at Mullanphy Hospital, St. Louis, where he had been under treatment for a long time, aged 72 .

Warren Montgomery Sweetland, M.D. Rush Medical College, Chicago, 1848, for twenty-five years a resident and practitioner of Highland Park, 1ll., who retired from active prac- 